ANUVA Volume 1 (1): 49-59, 2017

Copyright C2017, ISSN: 2598-3040 online

Available Online at: http://ejournal.undip.ac.id/index.php/anuva

\title{
Penggunaan Standar Baku Bahasa dan Penulisan Skripsi oleh Mahasiswa Prodi S-1 IImu Perpustakaan Fakultas IImu Budaya Undip dari Laporan Skripsi Tahun 2010 - 2014
}

\author{
Jumino $^{1 *}$ \\ ${ }^{1}$ Program Studi S-1 Sastra Inggris, Fakultas Ilmu Budaya, Universitas Diponegoro, \\ Jl. Prof. Soedarto, SH, Tembalang, Semarang. \\ ${ }^{*}$ Korespondensi: juminoya@gmail.com
}

\begin{abstract}
The ability to search information is very important for students, especially when they write thesis. Whether they are able to understand information during the course of their studies is evident from the thesis reports they write. This article discusses how in the ability of student information search based on S-1 students thesis reports of Library Science Faculty of Humanities Diponegoro University, thesis reports 2010 to 2014. Methods of data collection is done documentatively, then the data were processed by using qualitative methods to analyze the use of formal language standard, systematic report writing, and the thesis bibliography. The analysis shows that there are still many mistakes that students do in writing thesis. This indicates that there is still need for improvement of the system of teaching and writing guidance in order to obtain maximum results in writing thesis reports later on.
\end{abstract}

Keywords: information search, formal language standard, systematic writing, thesis report, bibliography

\begin{abstract}
Abstrak
Kemampuan pencarian informasi sangat penting bagi para mahasiswa, terutama ketika mereka menulis skripsi. Apakah mereka mampu memahami informasi selama masa studinya terlihat dari laporan skripsi yang mereka tulis. Dalam artikel ini dibahas seberapa dalam kemampuan pencarian informasi mahasiswa berdasarkan laporan skripsi mahasiswa S-1 Ilmu Perpustakaan Fakultas Ilmu Budaya Universitas Diponegoro laporan skripsi tahun 2010 sampai dengan 2014. Metode pengumpulan data dilakukan secara dokumentatif, kemudian data diolah dengan menggunakan metode kualitatif untuk menganalisis tentang penggunaan standar baku bahasa, sistematika penulisan laporan, dan bibliografi skripsi. Hasil analisis menunjukkan bahwa masih banyak kesalahan yang mahasiswa lakukan dalam penulisan skripsi. Hal ini menunjukkan bahwa masih diperlukan adanya pembenahan dan peningkatan terhadap sistem pengajaran dan pembimbingan penulisan agar diperoleh hasil yang lebih maksimal dalam penulisan laporan skripsi di kemudian hari.
\end{abstract}

Kata Kunci: pencarian informasi, standar baku bahasa, sistematika penulisan, laporan skripsi, bibliografi

\section{Pendahuluan}

Agar dapat melaksanakan riset dengan baik, seorang mahasiswa harus memiliki ketrampilan sebagai peneliti. Terlebih lagi di era informasi seperti saat ini, informasi sangat melimpah dan mudah agar diperoleh. Namun jika mahasiswa yang sedang melatih dirinya untuk menjadi peneliti tidak mawas diri, mereka dapat terjebak dalam informasi yang tidak relevan bahkan tidak valid. Untuk dapat memiliki ketrampilan yang harus dimiliki oleh mahasiswa dalam melaksanakan riset, seorang mahasiswa 
memerlukan ketrampilan khusus sebagai penunjang kegiatan riset, ketrampilan tersebut adalah pencarian informasi.

Mahasiswa jenjang strata 1 Fakultas Ilmu Budaya Universitas Diponegoro diwajibkan membuat laporan skripsi sebagai syarat kelulusan. Penulisan skripsi tentu saja tidak terlepas dari penggunaan bahasa baku, sitematika penulisan skripsi dan bibliografi. Laporan skripsi merupakan karya ilmiah yang harus menggunakan kosa kata bahasa Indonesia ynag baku, disusun dengan menggunakan sistematika penulisan yang standar, dan dilengkapi bibliografi dengan penulisan sesuai aturan. Untuk melaksanakan hal tersebut tentunya tidak terlepas dari kemampuan pencarian informasi terhadap ilmu yang telah mereka pelajari.

Penggunaan standar baku bahasa merupakan penggunaan kosakata bahasa Indonesia dengan baik dan benar sesuai aturan dari lembaga bahasa. Sistematika penulisan laporan merupakan sitem penomoran yang digunakan dalam penuliasan laporan skripsi. Adapun sitematika penulisan bibliografi skripsi merupakan aturan bagaimana cara menuliskan bibliografi secara baik dan benar.

Berdasarkan latar belakang tersebut peneliti tertarik untuk menngekplorasi bagaimana penggunaan standar baku bahasa, sistematika penulisan laporan dan bibliografi skripsi mahasiswa S-1 Program Studi Ilmu Perpustakaan Universitas Diponegoro. Meskipun para mahasiswa sudah mendapatkan bekal tentang pengetahuan bahasa Indonesia dan teknik penulisan ilmiah, mereka masih saja melaksanakan banyak kesalahan dalam penulisan laporan skripsi.

\section{Tinjauan Literatur}

\subsection{Perkembangan Istilah Pencarian informasi}

Istilah pencarian informasi sudah mulai berkembang di AS sejak tahun 1970an, istilah pencarian informasi pertama kali muncul pada tahun 1974 yang dilaporkan oleh Paul G. Zurkowski, menulis atas nama the National Commission On Libraries and Information Science. Ia menggunakan istilah ini untuk menggambarkan keterampilan dan teknik yang dimiliki seseorang yang literat informasi untuk memanfaatkan sejumlah sarana informasi yang juga sebagai sumber utama dalam membuat solusi informasi terhadap masalah mereka. Pencarian informasi merupakan keterampilan yang dipergunakan untuk mengenali informasi yang diperlukan, kemampuan memperoleh, mengevaluasi, dan memanfaatkan informasi tersebut secara efektif.

America Library Accociation Presidential Commitiee on information Literacy (1918) menghimbau agar orang mengembangkan literasi infomasi untuk ikut ambil bagian dalam dinamika masyarakat informasi. Dalam laporan tersebut, pencarian informasi dirumuskan sebagai kemampuan untuk mengenali apabila informasi itu diperlukan; mempunyai kemampuan untuk mendapatkan, mengevaluasi, dan menggunakan informasi secara efektif, dan menekankan bahwa pencarian informasi itu penting untuk long life learning.

Definisi pencarian informasi juga diberikan oleh Doyle (1994) yang menyatakan bahwa pencarian informasi merupakan kemampuan untuk mengakses, mengevaluasi dan menggunakan informasi dari berbagai sumber. 


\subsection{Kemampuan Pencarian informasi Sebagai Penunjang Kegiatan Riset}

Segenap kegiatan belajar mengajar yang dilakukan oleh mahasiswa yaitu semenjak semester satu, mereka telah dilatih untuk melaksanakan riset. Pelatihan tersebut terangkum dalam keterlibatan mahasiswa dalam mengobservasi sebuah fenomena alam atau sosial, kemudian mengumpulkan data dari hasil observasi, dan membuat laporan dari data yang didapat. Mahasiswa dilatih dan dibimbing untuk menyususn rencana riset sampai dengan penyususnan laporan riset.

Agar dapat melaksanakan riset dengan baik, seorang mahasiswa harus memiliki karakteristik seorang peneliti. Terlebih lagi di era informasi seperti saat ini, informasi sangat melimpah dan mudah diperoleh. Namun jika mahasiswa yang sedang melatih dirinya untuk menjadi peneliti tidak mawas diri, dia dapat terjebak dalam informasi yang tidak relevan bahkan tidak valid. Lebih lanjut lagi, Donaldson (2004) memberikan 9 ketrampilan yang harus dimiliki oleh mahasiswa dalam melaksanakan riset di era informasi kini, yaitu:

1. Fokus pada topik (persempit topik/perluas ruang lingkup)

2. Bekerja dalam urutan kronologis terbalik, pertama kali menelusur infromasi terbaru

3. Memahami signifikansi terminologi dan tentukan tajuk subjek yang benar

4. Menganekaragamkan sumber (gunakan buku, majalah, situs internet,dll)

5. Gunakan strategi Boelean (AND,OR,NOT) pada penelusuran komputer

6. Gandakan sumber sampai tiga kali (identifikasi sebanyak tiga kali rujukan dari yang diperlukan)

7. Evaluasi secara kritis materi yang ditemubalik; harus memiliki kecurigaan pada sumber yang berasal dari Web;

8. Asimilasikan informasi; jangan plagiat, masukkan gagasan sendiri ke dalam topik riset

9. Sitir semua sumber

Untuk dapat memiliki 9 keterampilan yang harus dimiliki oleh mahasiswa dalam melaksanakan riset, seorang mahasiswa memerlukan ketrampilan khusus sebagai penunjang kegiatan riset, ketrampilan tersebut adalah pencarian informasi. Lebih lanjut lagi Association of College and Research Libraries (2000) memberikan deskripsi karakteristik mengenai seseorang yang memiliki kemampuan pencarian informasi. Orang yang memiliki kemampuan pencarian informasi adalah mereka memiliki kemampuan untuk:

1. Menentukan informasi yang dibutuhkan

2. Mengakses kebutuhan informasinya secara efektif dan efisien

3. Mengevaluasi informasi dan sumber-sumber yang didapatkannya secara kritis.

4. Menggabungkan Informasi yang dipilihnya menjadi sebuah landasan pengetahuan

5. Menggunakan informasi secara efektif untuk mencapai tujuan tertentu 
6. Mengetahui isu-isu ekonomi, hukum, dan sosial seputar pengguanaan informasi, serta menggunakan informasi secara etis dan legal

\section{Analisis Data dan Pembahasan}

Analisis data adalah proses penyederhanaan data ke dalam bentuk yang lebih mudah untuk dibaca dan diintepretasikan (Effendi: 2012). Data-data yang telah diperoleh kemudian diolah untuk dianalisis. Setelah data dianalisis dan informasi yang lebih sederhana diperoleh, kemudian dilakukan interpretasi untuk menemukan makna dan implikasi yang lebih luas dari hasil-hasil riset.

\subsection{Standar Baku Penggunaan Bahasa}

Berikut ini merupakan analisis laporan skripsi mahasiswa S-1 Ilmu Perpustakaan Universitas Diponegoro terkait standar baku penggunaan bahasa. Masing masin tahun pengumpulan skripsi diwakili oleh dua laporan skripsi. Jadi ada 10 laporan skripsi secara keseluruhan. Untuk analisis kesalah penggunaan standar baku bahasa difokuskan pada kesalahan-kesalahan yang lazim muncul terkait ejaan, tanda baca, aturan penulisan, dan struktur kalimat. Berikut ini analisis dari masing-masing laporan skripsi yang dipilih.

\subsubsection{Laporan Skripsi Berjudul "Ketepatan Seleksi Bahan Perpustakaan di Kantor Perpustakaan dan Arsip Daerah Kabupaten Banyumas" oleh Fajar Dian Utami NIM A2D006012, Laporan Skripsi Tahun 2010}

Dalam laporan skripsi tulisan Fajar Dian Utami ini ditemukan kesalahan berikut. Pertama, terkait ejaan, ditemukan kesalahan seperti "obyek" pada halaman 21, yang seharusnya "objek" dan "satatistik", yang seharusnya ditulis "statistik". Kedua, terkait penulisan kata depan, ditemukan kesalahan seperti "diatas" pada halaman, 22, yang seharusnya ditulis "di atas" dan "dibidangnya" pada halaman 59, yang seharusnya ditulis "di bidangnya". Ketiga, terkait penulisan kata asing, ditemukan kesalahan seperti "Coding" pada halaman 25, yang seharusnya ditulis "Coding". Keempat, terkait penulisan kata kerja pasif, ditemukan kesalahan seperti "di pinjam" pada halaman 43, yang seharusnya ditulis "dipinjam"; Kelima, terkait struktur kalimat, ditemukan kesalahan seperti "Yaitu akurasi, kecermatan, ketelitian atau presisi (Endarmoko, 2007: 661)." pada halaman 6, yang seharusnya dilengkapi subjek. Keenam, terkait kelugasan makna, ditemukan kesalahan seperti "sebanyak 1 responden (1\%)," pada halaman, yang seharusnya ditulis "sejumlah 1 responden (1\%)," . Ketujuh, terkait penulisan huruf kapital, ditemukan kesalahan seperti "rumus slovin" pada halaman 25, yang seharusnya ditulis "rumus Slovin".

\subsubsection{Laporan Skripsi Berjudul "Perilaku Pencarian Informasi Pemustaka pada Layanan Referensi di Kantor Perpustakaan Daerah Jawa Tengah” oleh Andrea Ardi Ananda NIM.} A2D006004, Laporan Skripsi Tahun 2010

Dalam laporan skripsi tulisan Andrea Ardi Ananda ini ditemukan kesalahan berikut. Pertama, terkait ejaan, ditemukan kesalahan seperti "koleksi referens" pada halaman 11, yang seharusnya ditulis "koleksi referensi". Kedua, terkait penulisan kata tugas, ditemukan kesalahan seperti "Perilaku Pencarian Informasi Pemustaka Pada Layanan Referensi di Kantor Perpustakaan Daerah Jawa Tengah” pada 
halaman ix, yang seharusnya ditulis "Perilaku Pencarian Informasi Pemustaka pada Layanan Referensi di Kantor Perpustakaan Daerah Jawa Tengah”. Ketiga, terkait penulisan bukan kata asing, ditemukan kesalahan seperti "ada enam pola pencarian informasi yang urutannya adalah inisiasi, seleksi, eksplorasi, formulasi, koleksi dan presentasi" pada halaman 2, yang seharusnya ditulis "ada enam pola pencarian informasi yang urutannya adalah inisiasi, seleksi, eksplorasi, formulasi, koleksi dan presentasi”. Keempat, terkait penulisan kata kerja pasif, ditemukan kesalahan seperti "Jika di rata-rata dari 50 pengunjung " pada halaman 4, yang seharusnya ditulis "Jika dirata-rata dari 50 pengunjung ". Kelima, tterkait penulisan huruf kapital, ditemukan kesalahan seperti "Menurut Saracevic (Harisanty, 2009: 3) Informasi adalah" pada halaman 15, yang seharusnya ditulis "Menurut Saracevic (Harisanty, 2009: 3) informasi adalah", dan "Pasal 5 yaitu Untuk melaksanakan tugas pokok sebagaimana dimaksud dalam pasal 4," pada halaman 63, yang seharusnya ditulis "Pasal 5 yaitu untuk melaksankan tugas pokok sebagaimana dimaksud dalam pasal 4,”. Keenam, terkait struktur kalimat, ditemukan kesalahan seperti "Menurut Saleh dan Sujana (2009: 89) menyatakan informasi merupakan" pada halaman 15, yang seharusnya ditulis "Menurut Saleh dan Sujana (2009: 89), informasi merupakan". Ketujuh, terkait penulisan kata asing, ditemukan kesalahan seperti "human information searching behaviour" pada halaman 28, yang seharusnya ditulis "human information searching behaviour".

\subsubsection{Laporan Skripsi Berjudul "Pengaruh Tat Ruang Layanan terhadap Minat Berkunjung Pemustaka di Perpustakaan Khusus Dinas Kesehatan Provinsi Jawa tengah" oleh Fransiska Septiana NIM A2D007016, Laporan Skripsi Tahun 2011}

Dalam laporan skripsi tulisan Fransiska Septiana ini ditemukan kesalahan berikut. Pertama, terkait penulisan huruf kapital, ditemukan kesalahan seperti "menyatakan bahwa Agar kenyamanan ruangan perpustakaan terjaga," pada halaman 24 , yang seharusnya ditulis "menyatakan bahwa agar kenyamanan ruangan perpustakaan terjaga,". Kedua, terkait pemaknaan, ditemukan kesalahan seperti "antara lain" pada halaman 35, yang seharusnya ditulis "yaitu/ sebagai berikut". Ketiga, terkait penggunaan kata sambung, ditemukan kesalahan seperti "Berdasarkan data tersebut, maka dapat disimpulkan bahwa" pada halaman 64, yang seharusnya ditulis "Berdasarkan data tersebut, dapat disimpulkan bahwa". Keempat, terkait penulisan penulisan judul, ditemukan kesalahan seperti "Ensiklopedi Nasional Indonesia jilid 16" pada halaman 10, yang seharusnya ditulis "Ensiklopedi Nasional Indonesia jilid 16". Kelima, tterkait penulisan kalimat kompleks, ditemukan kesalahan seperti "Hal ini dapat dibuktikan dengan adanya sebagian besar responden yaitu 62,3\% (43 responden) menyatakan setuju" pada halaman 69, yang seharusnya ditulis "Hal ini dapat dibuktikan dengan adanyasebagian besar responden yaitu 62,3\% (43 responden) yang menyatakan setuju,". Keenam, terkait struktur kalimat, ditemukan kesalahan seperti "Dengan demikian diharapkan akan mampu meningkatkan produktifitas dan efektifitas." pada halaman 30, yang seharusnya kalimat tersebu dilengkapi subjek. 


\subsubsection{Laporan Skripsi Berjudul "Persepsi Pemustaka terhadap Desain InteriorRuang} Sampoerna Corner di UPT Perpustakaan Universitas Diponegoro Semarang” oleh Bahtiar Fitrian NIM A2D007009, Laporan Skripsi Tahun 2011

Dalam laporan skripsi tulisan Bahtiar Fitrian ini ditemukan kesalahan berikut. Pertama, terkait ejaan, ditemukan kesalahan seperti "disebapkan" pada halaman 28, yang seharusnya ditulis "disebabkan". Kedua, terkait struktur kalimat, ditemukan kesalahan seperti "Dengan penataan yang baik akan memberikan kepuasan fisik" pada halaman 17, yang seharusnya ditulis "Penataan yang baik akan memberikan kepuasan fisik". Ketiga, terkait penulisan huruf kapital, ditemukan kesalahan seperti "Apakah menurut anda bentuk perabot di ....." pada halaman 54, yang seharusnya ditulis "Apakah menurut aAnda bentuk perabot di .....". Keempat, terkait penulisan kata asing, ditemukan kesalahan seperti "untuk didisplay bersama" pada halaman 47, yang seharusnya ditulis "untuk di-display bersama". Kelima, terkait pemaknaan, ditemukan kesalahan seperti "sebanyak 10 responden) Informasi adalah" pada halaman 41, yang seharusnya ditulis "sejumlah 10 responden". Keenam, terkait penulisan kata depan, ditemukan kesalahan seperti "penghuni didalamnya" pada halaman 29, yang seharusnya ditulis "penghuni di dalamnya".

\subsubsection{Laporan Skripsi Berjudul "Pemanfaatan Software Senayan di Perpustakaan}

Perguruan Tinggi Bagian Neurologi Fakultas Kedokteran Universitas Diponegoro” oleh Dewi Maharani Rachmaningsih NIM A2D008015, Laporan Skripsi Tahun 2012

Dalam laporan skripsi tulisan Dewi Maharani Rachmaningsih ini ditemukan kesalahan berikut. Pertama, terkait penulisan kata asing dan nama diri, ditemukan kesalahan seperti "software senayan" pada halaman 9, yang seharusnya ditulis "software Senayan". Kedua, terkait ejaan, ditemukan kesalahan seperti "Prosentase" pada halaman 33, yang seharusnya ditulis "Persentase". Ketiga, terkait penggunaan kata baku, ditemukan kesalahan seperti "Kesimpulan" pada halaman 34, yang seharusnya ditulis "Simpulan". Keempat, terkait penulisan kata asing, ditemukan kesalahan seperti "Towards Library User's Satisfaction" pada halaman 19, yang seharusnya ditulis “Towards Library User's Satisfaction”. Kelima, tterkait penulisan kata depan, ditemukan kesalahan seperti “didalamnya) Informasi adalah" pada halaman 68, yang seharusnya ditulis "di dalamnya. Keenam, terkait penulisan kata kerja pasif, ditemukan kesalahan seperti "dapat di rinci” pada halaman 28, yang seharusnya ditulis "dapat dirinci”. Ketujuh, terkait penulisan judul buku dan kata majemuk, ditemukan kesalahan seperti "dalam bukunya berjudul Dasar - Dasar Ilmu Perpustakaan" pada halaman 27, yang seharusnya ditulis "dalam bukunya berjudul Dasar-dasar Ilmu Perpustakaan".

\subsubsection{Laporan Skripsi Berjudul "Pengaruh Etika Propfesi Pustakawan terhadap Kepuasan} Pemustaka di Layanan Sirkulasi UPT Perpustakaan Politeknik Negeri Semarang” oleh Fitriana Wahyu Anugrahini NIM. A2D008024, Laporan Skripsi Tahun 2012

Dalam laporan skripsi tulisan Fitriana Wahyu Anugrahini ini ditemukan kesalahan berikut. Pertama, terkait pemaknaan, ditemukan kesalahan seperti "memberi manfaat diantaranya yaitu" pada halaman 5, 
yang seharusnya ditulis "memberi manfaat, yaitu". Kedua, terkait penulisan sub judul, ditemukan kesalahan seperti "Tabel V.18 Tanggapan Pemustaka Terhadap Kejelasan Informasi Dari Pustakawan........70" pada halaman xviii, yang seharusnya ditulis "Tabel V.18 Tanggapan Pemustaka terhadap Kejelasan Informasi dari Pustakawan........70”. Ketiga, terkait penulisan nama diri, ditemukan kesalahan seperti "pustakawan di inggris" pada halaman 17, yang seharusnya ditulis "pustakawan di Inggris". Keempat, terkait penulisan struktur kalimat, ditemukan kesalahan seperti "Sedangkan menurut Sudarsono (1991:1) menguraikan 4 hal penting" pada halaman 14, yang seharusnya ditulis "Sudarsono (1991:1) menguraikan 4 hal penting". Kelima, tterkait ejaan, ditemukan kesalahan seperti "dapat ditunjukan adanya" pada halaman 94, yang seharusnya ditulis "dapat ditunjukkan adanya". Keenam, terkait penulisan kata asing, ditemukan kesalahan seperti "teknik probabilitiy sampling, simple random sampling" pada halaman 33, yang seharusnya ditulis "teknik probabilitiy sampling, simple random sampling". Ketujuh, terkait penggunaan kata baku, ditemukan kesalahan seperti "dapat ditarik kesimpulan bahwa" pada halaman 15, yang seharusnya ditulis "dapat ditarik simpulan bahwa".

\subsubsection{Laporan Skripsi Berjudul "Pengaruh Ambiguitas Peran terhadap Kinerja} Pustakawan Pustakawan UPT Perpustakaan Universitas Diponegoro Semarang” oleh Ana Faridatunniswah NIM A2D309011, Laporan Skripsi Tahun 2013

Dalam laporan skripsi tulisan Ana Faridatunniswah ini ditemukan kesalahan berikut. Pertama, terkait penulisan sub judul, ditemukan kesalahan seperti "5.1.1.5 Ketidakpastian atau Kurang Adanya Balikan dari Unjuk Kerja” pada halaman 52, yang seharusnya ditulis "5.1.1.5 Ketidakpastian Atau Kurang Adanya Balikan Dari Unjuk Kerja". Kedua, terkait penulisan kata depan, ditemukan kesalahan seperti "termasuk kedalam jabatan fungsional" pada halaman 14, yang seharusnya ditulis "termasuk ke dalam jabatan fungsional”. Ketiga, terkait ejaan, ditemukan kesalahan seperti "dalam subyek tertentu" pada halaman 57, yang seharusnya ditulis "dalam subjek tertentu". Keempat, terkait penulisan kata asing, ditemukan kesalahan seperti "Terjadinya sampling error" pada halaman 67, yang seharusnya ditulis "Terjadinya sampling error". Kelima, tterkait penulisan judul, ditemukan kesalahan seperti "Riset ini berjudul pengaruh ambiguitas peran terhadap kinerja pustakawan UPT Perpustakaan Universitas Diponegoro" pada halaman xiii, yang seharusnya ditulis "Riset ini berjudul "Pengaruh Ambiguitas Peran terhadap Kinerja Pustakawan UPT Perpustakaan Universitas Diponegoro". Keenam, terkait struktur kalimat, ditemukan kesalahan seperti "Menurut Sumrall \& Sebastianelli dalam (Catharina:2001) menyatakan bahwa penyebab" pada halaman 8, yang seharusnya ditulis "Sumrall \& Sebastianelli dalam (Catharina:2001) menyatakan bahwa penyebab".

\subsubsection{Laporan Skripsi Berjudul “ Kebutuhan dan Pencarian Informasi oleh Siswa di Perpustakaan SMK Negeri 11 Semarang” oleh Atia Maulana Dewi NIM A2D308002, Laporan Skripsi Tahun 2013}

Dalam laporan skripsi tulisan Atia Maulana Dewi ini ditemukan kesalahan berikut. Pertama, terkait penggunaan kata sambung, ditemukan kesalahan seperti "Dan sebanyak 69 orang siswa atau" pada 
halaman 61, yang seharusnya ditulis "Sebanyak 69 orang siswa atau". Kedua, terkait penulisan kata asing, ditemukan kesalahan seperti "browsing" pada halaman 21, yang seharusnya ditulis "browsing". Ketiga, terkait penulisan ejaan, ditemukan kesalahan seperti "Obyek wawancara" pada halaman 31, yang seharusnya ditulis "Objek wawancara". Keempat, terkait struktur kalimat, ditemukan kesalahan seperti "Adapun tujuan riset ini untuk menggambarkan" pada halaman 27, yang seharusnya ditulis "Adapun tujuan riset ini adalah untuk menggambarkan". Kelima, tterkait penulisan tanda baca, ditemukan kesalahan seperti "Menurut Lasa(1998:65), pencarian informasi adalah" pada halaman 23, yang seharusnya ditulis "Menurut Lasa (1998: 65), pencarian informasi adalah". Keenam, terkait penggunaan kata baku, ditemukan kesalahan seperti "Sedangkan definisi perpustakaan yang dikemukakan oleh Perpustakaan Nasional RI (2005:4) adalah" pada halaman 12, yang seharusnya ditulis "Adapun definisi perpustakaan yang dikemukakan oleh Perpustakaan Nasional RI (2005:4) adalah”.

\subsubsection{Laporan Skripsi Berjudul “ Analisis Media Promosi terhadap Minat Kunjung di} Kantor Perpustakan Arsip dan Dokumentasi Kabupaten Sukoharjo” oleh Aulia Lathifah

\section{NIM 13040110141061, Laporan Skripsi Tahun 2014}

Dalam laporan skripsi tulisan Aulia Lathifah ini ditemukan kesalahan berikut. Pertama, terkait pemaknaan, ditemukan kesalahan seperti "yang biasanya digunakan oleh organisasi antara lain:” pada halaman 10, yang seharusnya ditulis "yang biasanya digunakan oleh organisasi yaitu:". Kedua, terkait penggunaan huruf kapital, ditemukan kesalahan seperti "Selama ini perpustakaan sudah melaksanakan kegiatan peringatan hari anak nasional, hari buku dan hari kartini." pada halaman 4, yang seharusnya ditulis "Selama ini perpustakaan sudah melaksanakan kegiatan peringatan Hari Anak Nasional, Hari Buku dan Hari Kartini.". Ketiga, terkait penulisan sub judul, ditemukan kesalahan seperti "5.3.2.1 Perhatian Pemustaka Terhadap Keberadaan Perpustakaan Keliling" pada halaman 77, yang seharusnya ditulis “5.3.2.1 Perhatian Pemustaka terhadap Keberadaan Perpustakaan Keliling". Keempat, terkait penulisan kata sambung, ditemukan kesalahan seperti "Dan mencarinya bila diperlukan (Sugiyono, 2008: 247)." pada halaman 36, yang seharusnya ditulis "Selanjutnya dilakukan pencarian bila diperlukan (Sugiyono, 2008: 247).”. Kelima, tterkait penulisan tanda baca, ditemukan kesalahan seperti "Wawancara ( Interview )" pada halaman 44, yang seharusnya ditulis "Wawancara (Interview)". Keenam, terkait penulisan kaya kerja pasif, ditemukan kesalahan seperti "layanan yang di berikan di pepustakaan" pada halaman 109, yang seharusnya ditulis "layanan yang diberikan di pepustakaan". Ketujuh, terkait ejaan, ditemukan kesalahan seperti "tempat refresing" pada halaman 107, yang seharusnya ditulis "tempat refreshing". Kedelapan, terkait pebulisan kata depan, ditemukan kesalahan seperti "dibidang promosi" pada halaman 107, yang seharusnya ditulis "di bidang promosi".

\subsubsection{Laporan Skripsi Berjudul 'Pos Baca 'Merdeka' sebagai Strategi Promosi Perpustakaan dan Arsip Daerah Kabupaten Semarang (Studi Kualitatif mengenai Pos Baca ‘Merdeka' di RSUD Ungaran” oleh Doni Laksito Adi NIM 13040110141028, Laporan Skripsi Tahun 2014}


Dalam laporan skripsi tulisan Doni Laksito Adi ini ditemukan kesalahan berikut. Pertama, terkait penggunaan huruf kapital, ditemukan kesalahan seperti "dengan judul "Pengaruh Promosi Layanan Internet Terhadap Peningkatan Pengunjung Perpustakaan Di SMK Negeri 1 Semarang"" pada halaman 39, yang seharusnya ditulis "dengan judul "Pengaruh Promosi Layanan Internet terhadap Peningkatan Pengunjung Perpustakaan di SMK Negeri 1 Semarang"”. Kedua, terkait penggunaan kata baku, ditemukan kesalahan seperti "Kesimpulan awal yang" pada halaman 51, yang seharusnya ditulis "Simpulan awal yang" dan "dapat dianalisa bahwa" pada halaman 72, yang seharusnya ditulis "dapat dianalisis bahwa". Ketiga, terkait penulisan preposisi, ditemukan kesalahan seperti "Diantara sembilan informan" pada halaman 86, yang seharusnya ditulis "Di antara sembilan informan". Keempat, terkait struktur kalimat, ditemukan kesalahan seperti "Seperti yang diutarakan oleh Bapak Romlan, Mbak Sisi, dan Ibu Ika." pada halaman 84, yang seharusnya kalimat tersebit dilengkapi subjek.

\subsection{Penggunaan Standar Baku Sistematika Penulisan}

Setiap penulisan karya ilmiah memiliki sistematika penulisan yang berbeda. Perbedaan tersebut terkait format bagaimana suatu ide atau gagasan ditampilkan dalam bentuk karya tulis. Hal yang sama juga terjadi dalam penulisan skripsi.

Sebagai salah satu bentuk dari karya ilmiah, skripsi memiliki sistematika penulisan tersendiri. Sistematika ini harus dipatuhi oleh setiap mahasiswa yang menulis skripsi. Keberadaan standar baku sistematika penulisan laporan berfungsi sebagai salah satu kontrol kualitas laporan karya ilmiah mahasiswa dalam bentuk skripsi. Selain itu, standar baku tersebut juga berfungsi sebagai kegiatan penyegaraman konsep dan format skripsi yang dihasilkan. Oleh karena itu, selayaknya setiap skripsi yang dihasilkan oleh mahasiswa mengikuti standar baku penulisan yang ada.

Pertama, pengguaan simatika penulisan tidak konsisten, khususnya dalam sitem penomoran. Dalam penulisan laporan skripsi dapat digunakan sistimatika semua dengan anggka atau kombinasi. Seringkali kedua sitematika tersebut dicampuradukkan dan subsubnya terbolak-balik. Sebagai contoh setela sub a, seharusnya 1) tetapi 1 . Dan seterusnya.

Kedua, Penulisan subbab dimulai dengan huruf kapital semua atau sebaliknya hurup kecil senua. Sebagai contoh, "B. Pelestarian Bahan Pustaka Oleh Petugas Dan Rekanan" atau B. Pelestarian bahan pustaka oleh petugas dan rekanan". Seharusnya subbab tersebut ditulis "B. Pelestarian Bahan Pustaka oleh Petugas dan Rekanan" dan tulisan ditebalkan.

Ketiga, Konsistensi penulisan paragraf pertama di bawah subbah ada yang ditulis menjorok aada yang ditulis tidak dalam satu lapotan skripsi. Sebenarnya ini merupakan bagian dari selingkung penulisan laporan skripsi. Akan tetapi penulisan harus tetap konsisten.

\subsection{Penggunaan Standar Baku Penulisan Bibliografi}

Pada umumnya, kegiatan riset dimulai dengan pencarian ide yang bersumber dari berbagai jenis literatur yang tersedia. Literatur tersebut kemudian dikutip dan dicantumkan dalam bibliografi. Sebagai pedoman penulisan karya ilmiah mahasiswa, Program Studi Ilmu Perpustakaan Universitas Diponegoro telah 
menyusun standar baku penulisan skripsi. Standar baku tersebut berisi berbagai peraturan terkait penulisan skripsi, salah satunya adalah penulisan bibliografi. Idealnya, setiap skripsi yang dihasilkan oleh mahasiswa selalu mengikuti standar baku tersebut.

Kesalahan penulisan yang bersumber dari internet kebanyakan terjadi dalam penulisan tanggal akses. Kebanyakan bibliografi yang tertulis di skripsi mahasiswa menuliskan tanggal akses sumber yang berasal dari internet tanpa kurung siku. Seharusnya, dalam standar baku penulisan skripsi yang ada, penulisan tanggal akses berada dalam kurung siku.

Pada penulisan bibliografi yang bersumber dari buku, kesalahan yang peneliti temukan adalah penulisan judul buku. Beberapa mahasiswa menuliskan judul buku dalam bibliografi skripsi mereka dalam tanda petik (“). Beberapa lainnya menuliskan judul buku dalam huruf tegak (regular). Di sisi lain, standar baku mengharuskan penulisan judul buku dalam cetak miring tanpa tanda petik.

Penulisan bibliografi yang berasal dari skripsi/tesis/disertasi terletak pada penanda 'skripsi/tesis/disertasi' dan judul. Penulisan penanda 'skripsi/tesis/disertasi' seharunya terletak setelah judul. Namun banyak mahasiswa yang justru menuliskannya setelah penulisan tahun. Sedangkan penulisan judul seharusnya diletakkan dalam tanda kutip (“) dengan huruf bercetak tegak. Hasil riset menunjukkan bahwa beberapa mahasiswa menuliskannya dalam tanda petik dan bercetak miring (italic).

Banyak mahasiswa yang belum dapat membedakan antara judul artikel dengan judul jurnal. Hal ini terlihat adanya kesalahan penulisan bibliografi yang berasal dari majalah/jurnal, terutama pada penulisan judul artikel dan judul jurnal. Standar baku penulisan skripsi mengharuskan penulisan judul artikel bercetak tegak, sedangkan judul jurnal bercetak miring (italic). Hasil riset menunjukkan bahwa kesalahan yang sering terjadi adalah mahasiswa menuliskan judul artikel bercetak miring dan judul jurnal bercetak tegak. Hal yang sama juga terjadi dalam penulisan bibliografi yang bersumber dari makalah.

Kesalahan dalam penulisan bibliografi yang berasal dari undang-undang terjadi pada penulisan judul dan penanggung jawab. Penulisan judul undang-undang seharusnya bercetak miring, sedangkan yang terjadi justru sebaliknya. Banyak penulisan judul undang-undang yang bercetak tegak. Selain itu, beberapa bibliografi yang mencantumkan undang-undang juga tidak menampilkan dengan jelas siapa penanggung jawabnya. Hal ini mengakibatkan pembaca tidak mengetahui siapa yang bertanggung jawab terhadap isi dari undang-undang tersebut.

Kesalahan yang paling sedikit adalah penulisan bibliografi yang bersumber dari surat kabar dan brosur. Penulisan artikel surat kabar seharusnya lengkap mulai dari penanggung jawab, tahun, judul artikel, nama surat kabar, tanggal dan halaman pemuatan. Namun dalam penulisan bibliografi yang berasal dari artikel surat kabar, peneliti tidak menemukan nama penulis artikel yang dikutip. Sedangkan pada brosur, kesalahan yang terjadi adalah letak penanda 'brosur' yang seharusnya terletak setelah judul. Pada penulisan skripsi yang peneliti temukan, penanda 'brosur ' justru terletak di awal sebelum penanggung jawab.

\section{Simpulan}


Berdasarkan hasil analisis di atas dapat disimpulkan bahwa kesalahan kesalahan yang seringkali ditemukan dalam penulisan laporan skripsi oleh mahasiswa adalah sebagai berikut:

1. Penulisan kata depan yang seharusnya dipisah seringkali digandeng, seperti diatas :yang seharusnya di atas); dan awalan yang seharusnya digandeng malah dipisah, seperti di rata-rata (seharusnya dirata-rata).

2. Penulisan istilah asing yang dipaksakan dengan aturan dalam bahasa Indonesia, seperti mendownload, referens (yang seharusnya men-download, referensi).

3. Penggunaa huruf kapital bukan di awal kalimat, seperti menurut Saracevic, Informasi adalah ...(yang seharusnya Saracevic, informasi adalah ...)

4. Tidak adanya subjek di awal pengutipan, seperti Menurut Saleh dan Sujana (2009: 89) menyatakan ... (seharusnya Saleh dan Sujana (2009: 89) menyatakan ...)

5. Penulisan istilah-istilah asing yang tetap tegak, seperti human information searching behaviour (yang seharusnya human information searching behaviour)

6. Kesalahan dalam penulisan kata majemuk seperti Dasar-Dasar )yang seharusnya Dasar-dasar).

7. Penulisan kata depan dan kata sambung untuk judul yang seharusnya ditulis huruf kecil semua, seperti Tanggapan Pemustaka Terhadap Kejelasan Informasi Dari Pustakawan..... (seharusnya Tanggapan Pemustaka terhadap Kejelasan Informasi dari Pustakawan.....).

8. Kesalahan dalam penulisan judul artikel dan skripsi yang ditulis miring (seharusnya ditulis tegak dalam tanda petik)

9. Kesalahan penulisan sumber kutipan dari internet yang ditulis dalam tanda kurung, yang seharusnya dalan tanda kurung siku.

10. Pengulangan penulisan untuk beberapa pengarang yang sama yang seharusnya hanya ditulis sekali, selanjutnya diganti dengan garis bawah,

\section{Bibliografi}

Association of College and Research Libraries. (2000). "Information Literacy Competency". <http://www.ala.org/acrl/standards/informationliteracycompeteny>

Boekhorst, A. K. 2003. "Becoming information literate in the Netherlands". Library Review, Vol. 52.

Bungin, Burhan. 2005. Metodologi Penelitian Kuantitatif: Komunikasi, Ekonomi, dan Kebijakan Publik Serta Ilmu-ilmu Sosial Lainnya. Jakarta: Kencana.

CILIP. 2005. "Information Literacy: Definition." London: CILIP. <http://www.cilip.org.uk/professionalguidance/informationliteracy/definition>

Donaldson, Christy A. 2004. "Information Literacy and the McKinsey Model: The McKinsey Strategic Problem-Solving Model Adapted to Teach Information Literacy to Graduate Business Students". Library Philosophy and Practice Vol. 6.

Doyle, C.S. 1992. Outcome measures for information literacy. Final report to the National Forum on Information Literacy. Syracuse NY: ERIC Clearinghous.

Effendi, Sofian. 2012. Metode Penelitian Survei. Jakarta: LP3ES.

Prasetyo, Bambang. 2005. Metode Penelitian Kuantitatif: Teori dan Aplikasi. Depok: Raja Grafindo Persada.

Purwanto, Erwan Agus dan Diah Ratih Sulistyastuti. 2007. Metode Penelitian Kuantitatif untuk Administrasi Publik dan Masalah-masalah Sosial. Yogyakarta: Penerbit Gava Media. 